\title{
Risk factors for conversion to open surgery in laparoscopic cholecystectomy: a single center experience
}

\author{
Ali Sapmaz'(D), Ahmet Serdar Karaca² (D) \\ ${ }^{1}$ Clinic of General Surgery, Ankara City Hospital, Ankara, Turkey \\ ${ }^{2}$ Department of General Surgery, Baskent University İstanbul Hospital, İstanbul, Turkey
}

\begin{abstract}
Objective: This study aimed to demonstrate the demographic characteristics for laparoscopic cholecystectomy surgeries performed in the general surgery clinics of our hospital and to identify the rate of conversion to open surgery and the main reasons for convert to open surgery.

Material and Methods: Medical records of a total of 1.294 patients who underwent laparoscopic cholecystectomy in our hospital between October 2013 and May 2017 were retrospectively reviewed, and the rates of conversion to open surgery based on age groups were recorded.

Results: Of these patients, 1191 were females (92.0\%) and 103 (7.9\%) were males. Mean age was $48.6 \pm 13.2$ (range: 18 to 89 ) years. Indications for surgery were cholelithiasis in 1195 patients (92.4\%), acute cholecystitis in 56 patients (4.4\%), and gallbladder polyps in 43 patients (3.3\%). The procedure was conversion to open surgery in 41 patients (3.16\%), while $12(0.9 \%)$ developed intraoperative complications. There was no mortality. Mean length of hospital stay was 1.2 (range: 1 to 6 ) days. The main reasons for conversation to open surgery were as follows: adhesions in the Calot's triangle $(n=3)$, acute cholecystitis $(n=29)$, choledocholithiasis $(n=2)$, adhesions due to previous surgery $(n=1)$, dissection difficulty $(n=2)$, organ damage $(n=2)$, anatomic variation $(n=1)$, and stone expulsion $(n=1)$.
\end{abstract}

Conclusion: Acute cholecystitis appears to be the significant factor increasing the rate of conversation to open surgery during $L C$ procedures. Male sex and older age are the other factors increasing the risk of con- vert to open surgery. However, LC should be still the first choice of intervention.

Keywords: Laparoscopic cholecystectomy, open cholecystectomy, complication

Cite this article as: Sapmaz A, Karaca AS. Risk factors for conversion to open surgery in laparoscopic cholecystec tomy: a single center experience. Turk J Surg 2021; 37 (1): 28-32.

\section{Corresponding Author}

Ali Sapmaz

E-mail:asapmaz@gmail.com

Received: 27.09.2020

Accepted: 01.10 .2020

Available Online Date: 03.10 .2020

(- Copyright 2021 by Turkish Surgical Society Available online at www.turkjsurg.com

DOI: $10.47717 /$ turkjsurg.2020.4734

\section{INTRODUCTION}

Laparoscopic cholecystectomy (LC) is widely used worldwide as in Turkey and has become the standard approach for the treatment of symptomatic cholelithiasis in recent years (1). Major advantages of $L C$ including reduced postoperative pain, early return to normal physical activity, and improved cosmetic outcomes have made this method the first-line intervention over open cholecystectomy (OC). Several factors, which were previously definitive contraindications for $L C$, are currently diminished due to the recent improvements both in basic surgical concepts and in the technique used.

In the present study, we aimed to evaluate the outcomes of $L C$ in relation to several clinical parameters and compare data in the light of the literature data.

\section{MATERIAL and METHODS}

Medical records of a total of 1294 patients who underwent LC in the General Surgery Clinics of our hospital between October 2011 and October 2016 were retrospectively reviewed. (The study protocol was reviewed and approved by our Institutional Ethical Committee. Consent from our patients treated in our hospital is received to use them in the future when they are operated or treated. Although the study was retrospective, approval was obtained to use the related information. The procedures followed were in accordance with the Helsinki Declaration of 1975 as revised in 1983. IRB number: E-15/622) Data including age and sex of the patients, preoperative diagnosis, (acute cholecystitis- (muphy (+), leucocyto- 
sis, CRP elevation, gallbladder wall thickness is $>3 \mathrm{~mm}$ )) number of patients scheduled for laparoscopic surgery and conversion to open surgery, demographic characteristics of these patients, and the reasons for conversion to open surgery were recorded. The relation between age and sex, preoperative diagnosis, and the decision to convert to open procedure was evaluated. All LC operations were performed by the general surgeons of our clinics using standard four-port entry and under 12-14 mmHg pressure.

Based on preoperative ultrasonography findings, gallbladder wall thicknesses higher than $3 \mathrm{~mm}$ were considered to be "thick" and thicknesses equal to or lower than $3 \mathrm{~mm}$ were considered to be "normal".

\section{Statistical Analysis}

All data were recorded on "SPSS 17.0 for Windows" (SPSS Inc. Chicago IL.) statistical analysis software. For these variables, univariate analysis was performed using chi-square and Student's t-tests. Multivariate analysis was additionally performed for those variables that had statistical significance. $P$ values $<0.001$ were considered statistically significant.

\section{RESULTS}

Of all patients, 1191 (92.0\%) were females and 103 (7.9\%) were males. Mean age of females, males and overall study population was $44.8 \pm 12.3,49.6 \pm 11.2$, and $48.6 \pm 13.2$ years, respectively. Mean age of the males who underwent LC was significantly higher than females $(p<0.001)$. In total, the procedure was switched to open surgery in 41 patients (3.16\%), including 28 of 1,191 women (2.3\%) and 13 of 103 men (12.6\%). The rate of conversion to open surgery was higher among men compared to women $(p<0.001)$. Among the patients who were switched to open procedure, mean age of the women was $51.8 \pm 15.1$ years and mean age of the men was $57.9 \pm 14.8$ years, indicating a statistically significant difference $(p<0.05)$. Mean age of the patients who were switched to open surgery was $54.7 \pm 12.9$ years, and mean age of the patients who completed the surgery with laparoscopic method was $46.8 \pm 13.7$ years. Mean age of patients who switched to open surgery was statistically significantly higher $p<0.001$. (Table 1).
An evaluation of preoperative diagnoses showed that 1,195 patients were operated for cholelithiasis (92.4\%), 56 for acute cholecystitis (4.4\%), and 43 for gallbladder polyps (3.3\%). The procedure was conversion to open surgery in 18 patients operated for cholelithiasis (1.5\%) and in 23 patients operated for acute cholecystitis (41\%). The procedure was not switched to open surgery in any patient operated for gallbladder polyps. The rate of switch to open surgery was significantly higher among the patients operated for acute cholecystitis $(p<0.001)$.

Of the patients operated for acute cholecystitis, 22 were women (1.8\% of all female patients) and 34 were men (3.3\% of all male patients). The rate of operation due to acute cholecystitis was higher among men than women $(p<0.05)$.

Mean ages of the patients operated for acute cholecystitis and for cholelithiasis were 51.2 \pm 13.0 and $48.4 \pm 13.1$ years, respectively. Mean age of the patients operated for acute cholecystitis was significantly higher $(p<0.001)$ Table 2 shows the causes of conversion to open surgery in the absence of a complication. The most common cause was adhesions in the Calot's triangle.

Table 2 presents complications developed during laparoscopic surgery. The procedure was conversion to open surgery in all of those patients. One patient, who had cystic duct injury, was reoperated two days later due to ongoing bile drainage. Stomach-small intestine injuries occurred in two patients due to trocar entry and in two patients during dissection. Primary repair was performed in patients whose injuries occurred due to trocar entry. Primary repair and omentoplasty were performed for other patients. Since the injury was close to the conjunction point of the right and left hepatic ducts in 3 patients with choledochal injury, Roux-en-Y hepaticojejunostomy was performed for these patients. Choledochoduodenostomy was performed for the other patient.

\section{DISCUSSION}

The advantages of $L C$ over OC have been long discussed and now, LC has become the first choice $(1,2)$. Until May 2017, all 1294 cases in our hospital underwent LC. When this method was introduced, despite its advantages, it was not considered as a harmless procedure due to high rate of injuries particularly in the main bile ducts $(3,4)$. Acute cholecystitis accounts for almost

Table 1. The association of conversion with age and sex

\begin{tabular}{|l|c|c|}
\hline & $\mathbf{n}(\%)$ & $\mathbf{p}$ \\
\hline Age $($ Mean $\pm S D, y)$ & & $<0.005$ \\
$\quad$ Female & $51.8 \pm 15.1$ & $<0.005$ \\
Male & $57.9 \pm 14.8$ & \\
\hline Sex & $28(2.3 \%)$ & \\
$\quad$ Female & $13(12.6 \%)$ & \\
$\quad$ Male & & \\
\hline SD: Standard deviation, $y$ : Year. & & \\
\hline
\end{tabular}




\begin{tabular}{|l|c|}
\hline \multicolumn{2}{|l|}{ Table 2. Reasons of conversion } \\
\hline Reason & $\mathbf{n}(\%)$ \\
\hline Bile leak & $7(17 \%)$ \\
\hline Adhesion in Calot triangle & $6(14 \%)$ \\
\hline Cystic duct injury & $4(9.7 \%)$ \\
\hline Common bile duct stone & $4(9.7 \%)$ \\
\hline Common bile duct injury & $4(9.7 \%)$ \\
\hline Dissection difficulties & $4(9.7 \%)$ \\
\hline Stomach-small bowel injury & $4(9.7 \%)$ \\
\hline Adhesions due to previous surgery & $2(4.8 \%)$ \\
\hline Anatomic variations & $2(4.8 \%)$ \\
\hline Major abdominal vascular injury & $2(4.8 \%)$ \\
\hline Stone loss & $2(4.8 \%)$ \\
\hline
\end{tabular}

$20 \%$ of all gallbladder diseases, and it is no longer a contraindication for LC $(5,6)$. The incidence of biliary system injuries during $L C$ varies between $0.2-1.4 \%$. This rate, recorded among 11 cases in the present study (0.8\%), is consistent with the literature. Among those 11 cases, two had choledochal injury.

Etiology of sex differences in symptomatic cholelithiasis can be multifactorial (9) From a psychosocial perspective, men less frequently refer to a physician at symptom onset compared to women. Similarly, men agree to surgery at a later stage than women. This results in an increase in disease severity. Moreover, higher daily activities of men cause a delay in their referral to a hospital. From a pathophysiological perspective, women can be more sensitive to inflammatory changes associated with cholecystitis compared to men (9). Moreover, anatomic differences and changes in dietary habits may also result in the variability between men and women for cholelithiasis. The most common causes for switch to open surgery were adhesions in the Calot's triangle, acute cholecystitis and bleeding in the present study. In the study of Kausnik et al. (10), adhesions in the Calot's triangle and injuries of the main bile duct have been to be the most common causes of switch to open surgery.

As shown in Table 2, the most remarkable problems in cases switched to open surgery in the absence of a complication were adhesions in the Calot's triangle and difficulties in dissection. Previous upper abdominal surgeries are also risk factors increasing the rate of switch to open surgery (11).

The rate of major complications during $L C$ has been previously reported as $1-3 \%$, and the rate of bile duct injuries has been found to vary between 0 and $0.7 \%$ (3). Complications due to Veres and trocar entry have been previously reported in the literature. In a study conducted by Deizel et al. (12), intestinal perforation has been reported as the most common cause of death that occurs after laparoscopic methods. In the present study, four patients received treatment was by open surgery af- ter stomach-small intestine perforations which developed due to trocar entry and dissection.

The rate of conversion to open surgery due to bleeding has been reported as $0-1.9 \%$, and the rate of secondary surgeries has been found to be $0.4 \%$ (4-13). In the case series of Shurkalin et al. (14), bleeding has been noted in $0.7 \%$ of the patients, and the most common causes of bleeding have been determined intraoperative injuries accompanied by anatomic variations of the vessels (14). Epigastric vessel injury occurred due to trocar entry in two cases in this study; these complications were noticed and successfully treated during the operation. Mortality due to $L C$ is similar to $\mathrm{OC}$ and has been reported to vary between 0 and 0.9 $\%$ (15-17). Mortality frequently occurs due to concomitant diseases and peritonitis which develop as a result of intraabdominal organ injuries. None of the patients died in our patient series.

Assessment of age and sex distribution of the patients with acute cholecystitis indicated a higher rate of acute cholecystitis among men at all age groups. For both sexes, the rate of acute cholecystitis in the age group of 65 years or older was higher compared to the other age groups, and the difference reached statistical significance for men. Men with acute cholecystitis were younger compared to women.

In the study of Tocchi et al. (18), cholelithiasis complications have been more frequently observed in men, and male sex, as well as ages over 65 years, have been found to be factors negatively effecting operative mortality. Based on some series, higher rates of conversion to open surgery, morbidity and mortality have been reported among older patients (15-19). This is mostly associated with the frequency of cholecystitis episodes and concomitant diseases. Elective LC is recommended for older patients with symptomatic gallbladder stones before they experience an acute cholecystitis episode (20). In the present study, the rate of conversion to open surgery and the rate of complications were higher among patients older than 65 years, and the effect of age on the rate of complications was significant. On the other hand, older age had no significant effect on the duration of operation.

In the present study, acute cholecystitis was found to be the second most common cause of switch to open surgery. In a very large-scale study performed by Vecchio et al. (21) by reviewing data of more than 100.000 patients, the rate of switch to open surgery has been primarily associated with the severity of inflammation.

While patients with acute cholecystitis were initially not found eligible for $L C$, studies performed later on increased the experience on this procedure and demonstrated that $L C$ can be routinely performed in this patient group as well (22-24). Early cholecystectomy is known to be beneficial also for patients with acute cholecystitis(25). In the present study, the presence of acute cholecystitis and increased wall thickness as shown by 
USG were found to be risk factors for switch to open surgery, and their effects also reflected on the complications and duration of operation. These patients constitute the patient group, in whom LC must be performed by paying utmost attention and dissection must be done very carefully.

The rate of gallbladder injuries during $L C$ is higher than the rate observed during open surgery and has been reported to vary between 0.2 and $1.4 \%$ (26). Despite all precautions, the best time of repair in case of an injury appears to be during the operation. Hollow organ injuries are also commonly seen complications during $L C$ procedures. Some reports indicate that their incidence may reach up to $0.9 \%$ (26). Attention must be paid for such injuries, particularly while constructing the pneumoperitoneum and during the use of cautery. The rate of retroperitoneal major vessel injury due to trocar entry has been reported as $0.05 \%$ in the previous studies, and mortality associated with such injuries has been found to be $8.3 \%$ (12). Balija et al. (27) have evaluated bile duct variations in patients who underwent $L C$ and detected accessory bile ducts in $52 \%$ of their patients. In the present patient series, seven patients who had bladder bed leakage were followed-up by medical means and the leakage was successfully controlled by ERCP in one patient.

Complications due to cystic artery injury, which were previously reported in $0.2-2 \%$ of the patients, did not develop in any patient in the present patient series (23).

\section{CONCLUSION}

In conclusion, acute cholecystitis appears to be the most significant factor increasing the rate of conversation to open surgery during LC procedures. Male sex, older age, and the presence of acute cholecystitis are the main factors increasing the risk of convert to open surgery. However, LC must still be the first choice of intervention. We believe that the rate of complications will decrease even more, as we gain additional experience in the treatment of acute cholecystitis, in particular.

Ethics Committee Approval: The ethical approval for this study was obtained from Başkent University Medical And Health Sciences Research Board (Date: 02.02.2020 Decision no: 603339-604.01.02/13101).

Peer-review: Externally peer-reviewed.

Author Contributions: Concept - A.S., A.S.K.; Design - A.S.K., A.S.; Supervision - A.S., A.S.K.; Data Collection and/or Processing - A.S.K., A.S.; Analysis and Interpretation - A.S.K., A.S.; Literature Review - A.S.K., A.S.; Writing Manuscript - A.S., A.S.K.; Critical Reviews - A.S.K., A.S.

Conflict of Interest: The authors declare that they have no conflict of interest.

Financial Disclosure: The authors declared that this study has received no financial support.

\section{REFERENCES}

1. Troidl H, Spangenberger W, Langen R, al-Jaziri A, Eypasch E, Neugebauer E, et al. Laparoscopic cholecystectomy: technical performance, safety and patient's benefit. Endoscopy 1992; 24:252-61. [CrossRef]

2. Krämling H, Hüttl TP, Heberer G. Development of gallstone surgery in Germany. Surgical Endoscopy 1999; 13: 909-13. [CrossRef]

3. Daniel BJ, Nathaniel JS. Complications of laparoscopic cholecystectomy. Ann Rev Med 1996; 47: 31-44. [CrossRef]

4. Club Southern Surgeons. Postoperative analysis of 1518 laparoscopic cholecystectomies. N Engl J Med 1991; 324: 1685-8. [CrossRef]

5. Cuschieri A, Berci G, Mcsherry CK. Laparoscopic Cholecystectomy. Am J Surg 1990; 159: 273-5. [CrossRef]

6. Schirmer BD, Edge SB, Dix, Hyser MJ, Hanks JB, and Jones. Laparoscopic cholecystectomy. Treatment of Choice For Symptomatic Cholelithiasis. Ann Surgery 1991; 213: 665-76. [CrossRef]

7. Adamsen S, Hansen OH, Jensen PF, Schulze S, Stage JG, Wara P. Bile duct injury during laparoscopic cholecystectomy: a prospective nationwide series. J Am College Surgeons 184 (6); 571-8. [CrossRef]

8. Woods M, Traverso LM, Kozarek RA, Tsao J, Rossi RL, Gough D, et al. Characteristics Of Biliary tract complications during laparoscopic cholecystectomy: A multi-institutional study. Am J Surg 1994; 167: 27-34. [CrossRef]

9. Lein HH, Huang CS. Male gender: risk factor for severe symptomatic cholelithiasis. World J Surgery 2002; 26: 598-601. [CrossRef]

10. Kaushik R, Sharma R, Batra R, Yadav TD, Attri AK, Kaushik SP. Laparoscopic cholecystectomy: an Indian experience of 1233 cases. J Laparoendoscop Adv Surg Tech 2002; 12: 21-5. [CrossRef]

11. Curet MJ. Special problems in laparoscopic surgery: previous abdominal surgery, obesity, and pregnancy. Surg Clin North America 2000; 80: 1093-110. [CrossRef]

12. Deziel DJ, Millikan KW, Economou SG, Doolas A, Ko ST, Airan MC. Complications of laparoscopic cholecystectomy: a national survey of 4,292 hospitals and an analysis of 77,604 cases. Am J Surg 1993; 165: 9-14. [CrossRef]

13. Cuschieri A, Dubois F, Mouiel J, Mouret P, Becker H, Buess G, et al. The European experience with laparoscopic cholecystectomy. Am J Surg 1991; 161: 385-7. [CrossRef]

14. Shurkalin BK, Kriger AG, Gorskii VA, Ovanesian ER, Andreistev IL, Rzhebaev KE. Complications of laparascopic cholecystectomy. Vestn Khirlm I/ Grek 2001; 160: 78-83. [CrossRef]

15. Fried GM, Barkun JS, Sigman HH, Joseph L, Clas D, Garzon J, et al. Factors determining conversion to laparotomy in patients undergoing la paroscopic cholecystectomy. Am J Surg 1994; 167; 35-41. [CrossRef]

16. Unger SW, Rosenbaum G, Edelman DS. A comparison of laparoscopic and open treatment of acute cholecystitis. Surgicalendoscopy 1993; (7): 408-11. [CrossRef]

17. Göçmen E, Doğanay M, Karaayvaz M, Kama NA. Laparoskopik kolesistektomi: ilk 150 hastadaki erken sonuçlarımız. T Klin Gastroenterohepatol 1995; 6:132-7. [CrossRef]

18. Cates JA, Tompkins RK, Zinner MJ, Busuttil RW, Kolmann C, Roslyn JJ. Biliary complications of laparoscopic cholecystectomy. Am Surg 1993; 59: 243-7. [CrossRef]

19. Liu CL, Sheung-tat F, Edward CSL, Chung-mau L, Kentman C. Factors Affecting conversion of laparoscopic cholecystectomy to open surgery. ArchSurg 1996; 131 98-101. [CrossRef] 
20. Nielsen LBJ, Harboe KM, Bardram L. Cholecystectomy for the elderly: no hesitation for otherwise healthy patients. Surgical endoscopy 2014, 28.:171-7. [CrossRef]

21. Vecchio R, MacFadyen BV, Latteri S. Laparoscopic cholecystectomy: an analysis on 114,005 cases of United States series. Int Surg 1998; 83: 215-9. [CrossRef]

22. Keskin A, Bostanoglu S, Atalay F, Elbir O, Seven C, Arda K. Laparoskopik Kolesistektomide laparotomiye konversiyon. End- Lap ve Minimal invaziv Cerrahi 1996; 107-10. [CrossRef]

23. Miller RE, Kimmelstiel FM. Laparoscopic cholecystectomy for acute cholecystitis. Surg Endosc 1993; 296-9. [CrossRef]

24. Alabaz Ö, Sönmez H, Erkoçak EU, Camcı C, Dalyan O. Laparoskopik kolesistektomi:192 olgunun sunumu. End-Lap ve Minimal invaziv Cerrahi 1996; 94-9. [CrossRef]
25. Mestral CD, Rotstein OD, Laupacis A, Hoch JS, Zagorski B, Alali AS, Nathens $A B$. Comparative operative outcomes of early and delayed cholecystectomy for acute cholecystitis: a population-based propensity score analysis. Ann Surg 2014; 259: 10-5. [CrossRef]

26. Shamiyeh A, Wayand W. Laparoscopic cholecystectomy: early and late complications and their treatment. Langenbecks Arch Surg 2004; 389: 164-71. [CrossRef]

27. Balija M, Huis M, Szerda F, Bubnjar J, Stulhofer M. Laparoscopic cholecystectomy-accessory bile ducts. Acta Med Croatica 2003; 57: 105-9. [CrossRef]

28. Özgen A, Akata A, Arat FB, Demirkazık M, Özmen N, Akhan O. Gallbladder duplication: imaging findings and differential considerations. Abdom Imaging 1999; 24 :285-8. [CrossRef]

29. Dahnert W. Radiology Review Manual. $2^{\text {nd }}$ ed. Williams\&Wilkins 1993; 426. [CrossRef]

\title{
ORIJINAL ÇALIŞMA-ÖZET
}

Turk J Surg 2021; 37 (1): 28-32

\section{Laparoskopik kolesistektomide açığa dönüş risk faktörlerinde tek merkez deneyimi}

\author{
Ali Sapmaz ${ }^{1}$, Ahmet Serdar Karaca ${ }^{2}$ \\ ${ }^{1}$ Ankara Şehir Hastanesi, Genel Cerrahi Kliniği, Ankara, Türkiye \\ 2 Başkent Üniversitesi İstanbul Hastanesi, Genel Cerrahi Anabilim Dalı, İstanbul, Türkiye
}

\section{ÖZET}

Giriş ve Amaç: Bu çalışmadaki amacımız hastanemiz genel cerrahi kliniklerinde yapılan laparoskopik kolesistektomi ameliyatlarının demografik özelliklerini ortaya koymak, açık cerrahiye geçiş oranı ve başlıca nedenlerini irdelemektir.

Gereç ve Yöntem: Ekim 2013-Mayıs 2017 tarihleri arasında hastanemizde laparoskopik kolesistektomi uygulanan toplam 1.294 hastanın tıbbi kayıtları geriye dönük olarak incelendi ve yaş gruplarına göre açık cerrahiye geçiş oranları kaydedildi.

Bulgular: Bu hastaların 1191'i kadın (\%92,0) ve 103'ü $(\% 7,9)$ erkekti. Ortalama yaş 48,6 $\pm 13,2$ (18-89) yıldı. Ameliyat endikasyonları 1195 hastada (\%92,4) kolelitiazis, 56 hastada $(\% 4,4)$ akut kolesistit ve safra kesesi polipleriydi. 43 hasta $(\% 3,3)$. Işlem 41 hastada $(\% 3,16)$ açık cerrahiye geçerken, 12 hastada $(\% 0,9)$ intraoperatif komplikasyon gelişti. Ölüm olmadı. Ortalama hastanede kalış süresi 1,2 (1-6) gündü. Açık cerrahiye geçmenin ana nedenleri şunlardı: Calot üçgeninde yapışıklıklar ( $n=3)$, akut kolesistit $(n=29)$, koledokolitiazis $(n=2)$, önceki ameliyata bağlı yapışıklıklar $(n=1)$, diseksiyon zorluk $(n=2)$, organ hasarı $(n=2)$, anatomik varyasyon $(n=1)$ ve taş çıkarma $(n=1)$.

Sonuç: Akut kolesistit, laparoskopik kolesistektomi sırasında açık cerrahiye geçiş oranını artıran en önemli faktör olarak görünmektedir. Erkek cinsiyeti, artan yaş ve akut kolesistit varlığı açık cerrahiye dönüş riskini artıran ana faktörlerdir.

Anahtar Kelimeler: Laporoskopik kolesistektomi, kolesistektomi, komplikasyon

Doi: $10.47717 /$ turkjsurg.2020.4734 